\title{
Ekstrak Hirarki Data Dari Situs Web A-Z Animals Menggunakan Web Scraping
}

\author{
I Putu Arditya Darmawan ${ }^{1}$, I Nyoman Piarsa², I Putu Arya Dharmaadi ${ }^{3}$ \\ Program Studi Teknologi Informasi, Fakultas Teknik, Universitas Udayana \\ Kampus Unud, Bukit Jimbaran, Bali, Indonesia \\ 1putuarditya@gmail.com \\ 2manpits@unud.ac.id \\ 3aryadharmaadi@unud.ac.id
}

\begin{abstract}
Abstrak
A-Z Animals merupakan sebuah website yang menyajikan data mengenai Kingdom Animalia. Data Kingdom Animalia memiliki hirarki atau tingkatan yang disebut dengan tingkat takson, yang dimulai dari kingdom hingga species. Permasalahan yang dihadapi adalah data yang terdapat pada website tersebut dapat digunakan kembali untuk kepentingan lain, seperti membuat kamus, media pembelajaran dan lain-lain, namun diperlukan waktu yang cukup lama untuk memasukkan data ke database karena data yang terlalu banyak dan kompleks. Solusi dari permasalahan tersebut adalah membuat aplikasi yang dapat secara otomatis mengambil data dari website untuk mempercepat pengumpulan data. Web Scraping merupakan metode untuk mengambil dokumen sebuah website dari internet, yang berupa HTML, selanjutnya dilakukan analisis untuk diambil data tertentu dari dokumen tersebut. Hasil pengujian yang telah dilakukan menunjukkan bahwa aplikasi dapat mengambil konten atau data yang diperlukan dari website a-z-animal.com. Aplikasi membutuhkan waktu rata-rata untuk memproses satu buah halaman a-z-animal.com adalah sekitar 16.13 detik.
\end{abstract}

Kata kunci: Web Scraping, Kingdom Animalia, PHP, Ekstraksi Data.

\begin{abstract}
A-Z Animals is a website that presents data about Kingdom Animalia. The Kingdom Animalia data has a hierarchy or level called the taxon level, which starts from kingdom to species. The problems encountered are the data contained on the website can be reuse for other purposes, such as creating dictionaries, learning media and others, but it takes a long time to enter data into the database due to the many and the complexity of the data. The solution of the problem is to create an application that can automatically retrieve data from the website to speed up data collection.Web Scraping is a method to retrieve documents from a website from the internet, in the form of HTML, next analyzed to retrieve certain data from the document. The results of tests sowed applications can retrieve content or data required from the website a-z-animal.com. The application takes an average time to process one page of a-z-animal.com is about 16.13 seconds.
\end{abstract}

Keywords: Web Scraping, Kingdom Animalia, PHP, Data Extraction.

\section{Pendahuluan}

Informasi memiliki kaitan yang erat dengan kehidupan masyarakat pada zaman sekarang. Teknologi yang berkembang sekarang mendorong informasi dapat diterima dengan mudah dan cepat. Teknologi yang berkembang dengan pesat sekarang adalah internet. Menurut pakar internet Onno W. Purbo, Internet merupakan sebuah media yang dapat digunakan sebagai sarana untuk saling bertukar informasi, baik berupa web, VolP atau E-mail yang merupakan aplikasi dari internet [1]. Internet dapat mempermudah siapapun dalam pencarian informasi yang diinginkan.

Internet dapat digunakan dalam proses pengumpulan informasi, contohnya adalah search engine milik Google yang dapat membantu menjelajah di internet dengan mengumpulkan informasi dari 
website. Search engine melakukan proses pengumpulan data dari berbagai website menggunakan bot secara periodik [2].

Data yang terdapat pada sebuah website dapat diolah dan digunakan kembali untuk kepentingan lain, seperti membuat kamus, media pembelajaran dan masih banyak lagi. Pembuatan media pembelajaran klasifikasi mahkluk hidup [3], yang memerlukan data spesies yang banyak sebagai materi dari media pembelajaran tersebut [4]. Data klasifikasi mahkluk hidup memiliki struktur yang bertingkat atau hirarki yang disebut dengan tingkat taksonomi. Tingkat takson dimulai dari kingdom hingga spesies. Data taksonomi yang diperlukan dapat diambil dari internet secara manual, tetapi akan membutuhkan waktu yang cukup lama untuk memproses data tersebut.

Data dari website dapat dikumpulkan dengan banyak cara selain diproses manual, contohnya dengan menggunakan Wget. GNU Wget atau Wget adalah sebuah paket software gratis yang berfungsi untuk mengambil file atau dokumen dengan menggunakan protokol HTTP, HTTPS dan FTP. Wget adalah sebuah tool yang berbasis command line atau menggunakan baris perintah untuk menjalankannya. Pengambilan data yang dilakukan Wget adalah mengunduh dokumen dari halaman website secara penuh, untuk pengambilan data yang lebih spesifik atau mengambil bagian tertentu saja dari sebuah website dapat menggunakan web scraping [5],[6].

Penelitian mengenai pengambilan data dari website telah banyak dilakukan, contohnya penelitian yang dilakukan oleh Utomo yaitu "Web Scraping pada Situs Wikipedia menggunakan Metode Ekspresi Regular" [7]. Aplikasi yang dibangun dan ditanam pada web server yang terkoneksi dengan jaringan internet. Aplikasi berjalan menggunakan service http dengan format transaksi data html, sehingga aplikasi dapat dibuka menggunakan terminal yang terkoneksi ke jaringan komputer dan mempunyai browser web. User dapat melihat dokumen yang telah diekstrak dalam bentuk artikel dalam wordpress. Komputer Server berfungsi sebagai web server yang telah terpasang Wordpress. Web server mengambil halaman web dari wikipedia.org kemudian mengekstrak konten utama dari halaman tersebut dan menyimpannya kedalam bentuk artikel di Wordpress. Penelitian lainnya dilakukan oleh Josi dengan judul "Penerapan Teknik Web Scrapping pada Mesin Pencari Artikel IImiah" [2]. Aplikasi yang dibuat berupa web base yang diimplementasikan dengan metode web scraping pada aplikasi yang telah dibuat, hasil dari pencarian disimpan ke dalam tabel menggunakan database MySQL.

Latar belakang tersebut yang mendorong melakukan penelitian ini. Penelitian ini berfokus pada proses pengambilan data pada wesite A-Z Animals dan memanfaatkan model data tree untuk menyimpan tingkat takson yang ada. Model tree akan mempermudah dalam pemodelan dari sistem klasifikasi yang ada.

\section{Metodologi Penelitian}

\subsection{Gambaran Umum}

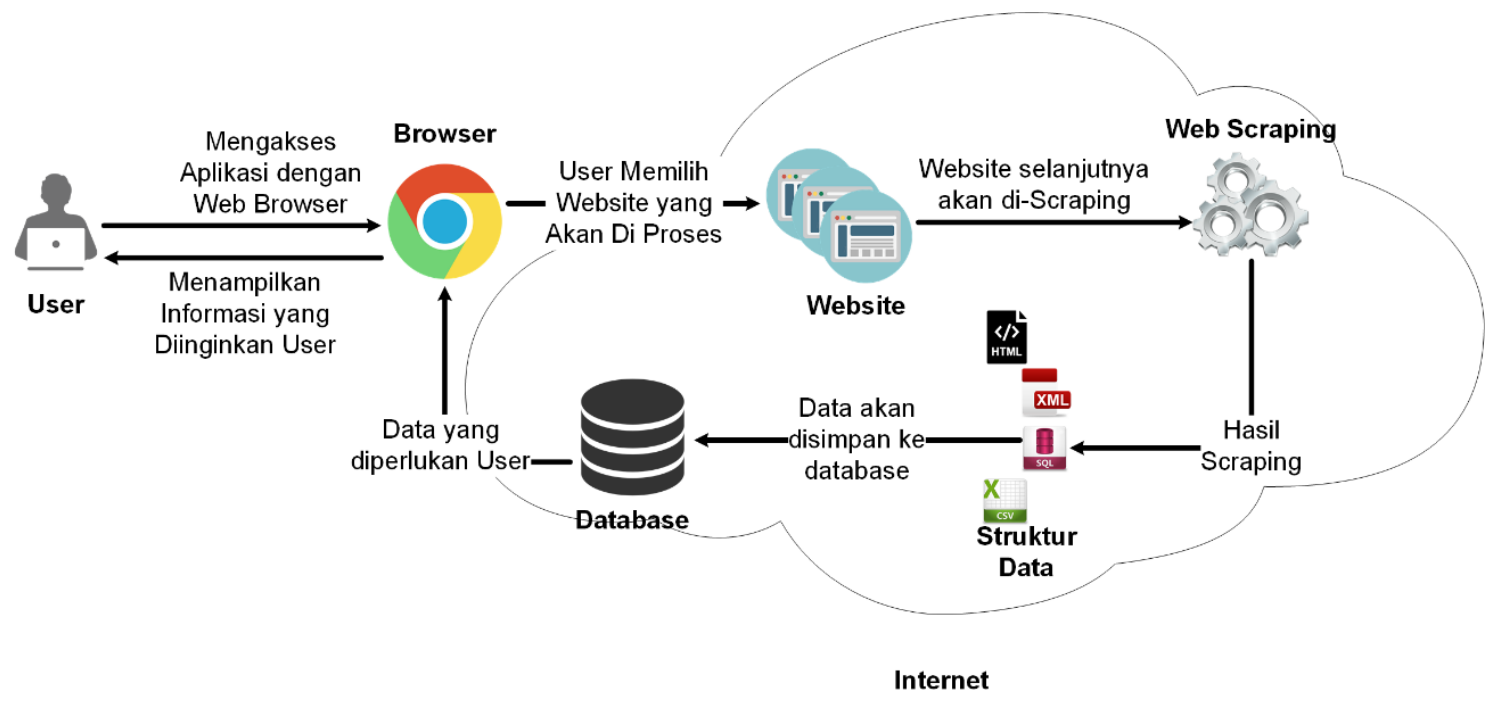

Gambar 1. Gambaran Umum Sistem 
Gambar 1 adalah gambaran umum dari aplikasi. Pertama user membuka web browser untuk mengakses aplikasinya, selanjutnya user memilih web yang diinginkan untuk diambil datanya. Web yang dipilih tersebut melanjutkan proses selanjutnya yaitu scraping, dalam proses scraping data yang diinginkan oleh user diekstrak dari web tersebut. Data yang berhasil diekstrak dari web tersebut disimpan di dalam database. Data yang disimpan tersebut digunakan oleh user untuk mendapatkan informasi yang diinginkan.

\subsection{Flowchart}

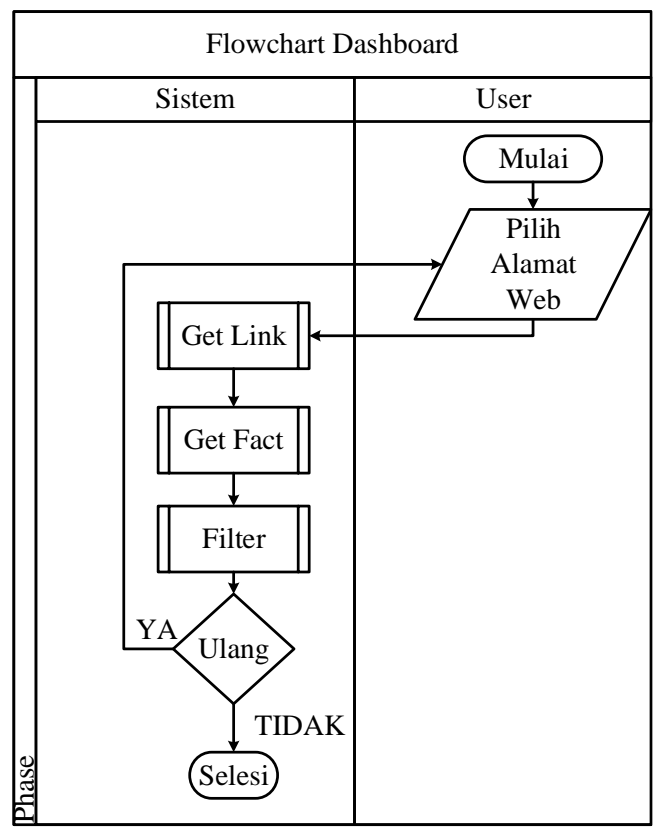

Gambar 2. Flowchart Dashboard

Gambar 2 flowchart ini menggambarkan alur kerja dari aplikasi. Terdapat tiga buah sub proses yaitu Get Link, Get Fact dan Filter yang dijelaskan sebagai berikut.

a. Get Link

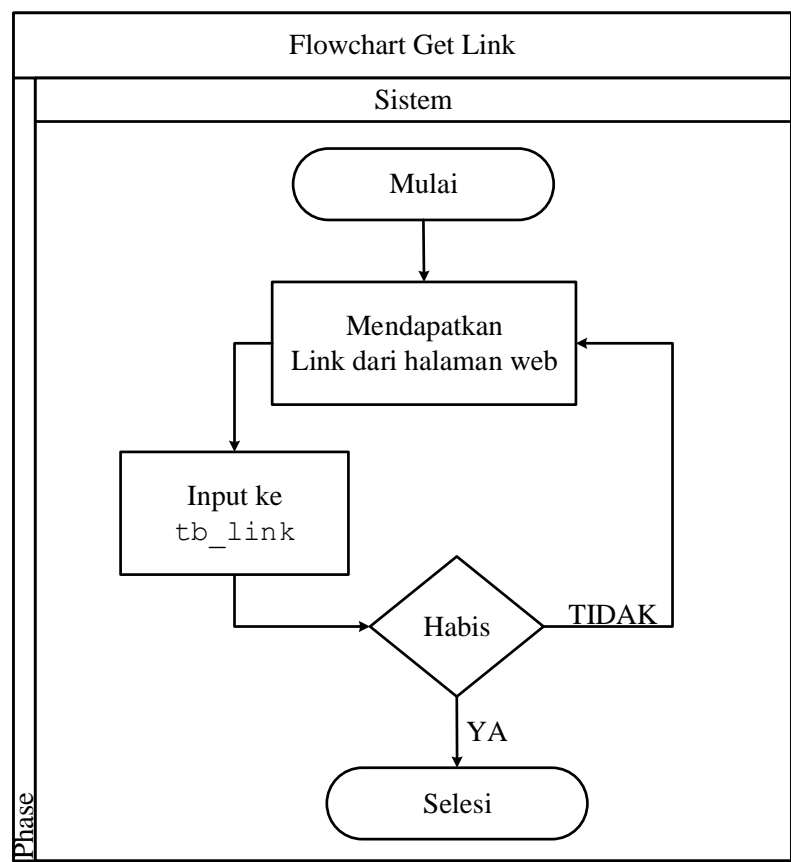

Gambar 3. Flowchart Get Link 
Gambar 3 merupakan tampilan flowchart sub program Get Link. Flowchart ini menggambarkan alur kerja dari sub program Get Link yang berfungsi untuk mengidentifikasi halaman web yang dipilih user untuk mendapatkan link yang menghubungkan ke bagian info animalia pada web tersebut. Link yang berhasil didapat disimpan dalam database yang selanjutnya link tersebut digunakan pada sub program Get Fact.

b. Get Fact

Get Fact merupakan sub proses yang berfungsi untuk mengambil fact atau data yang diinginkan dari website. Alur proses dari Get Fact dapat dilihat pada Gambar 4.

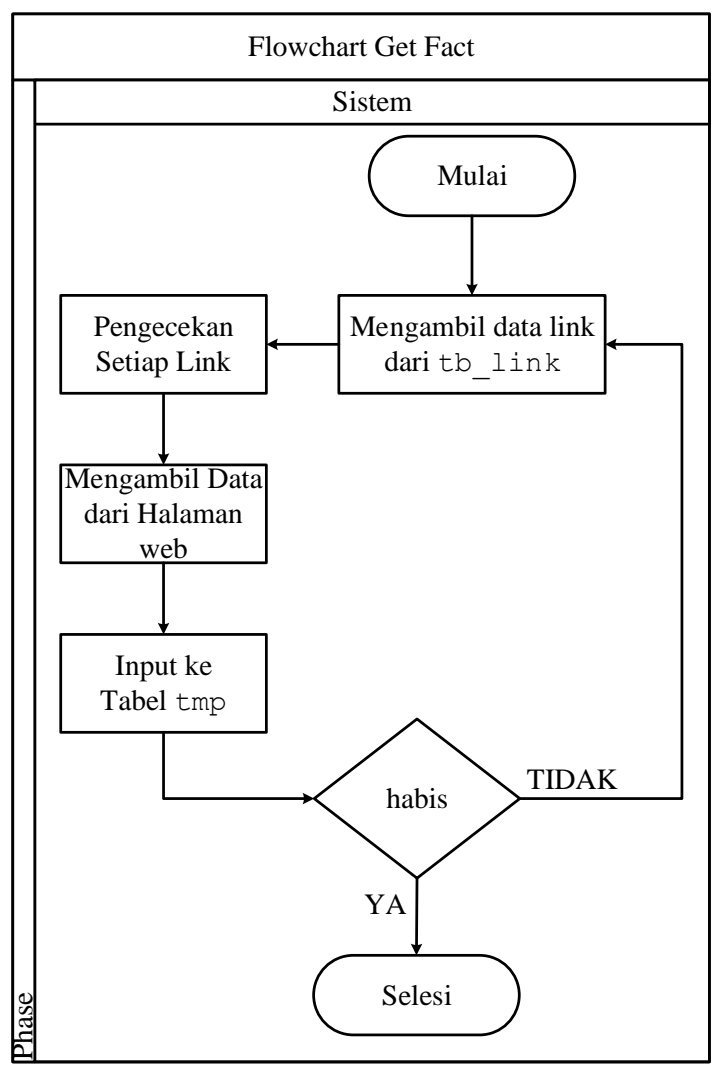

Gambar 4. Flowchart Get Fact

Gambar 4 merupakan tampilan flowchart sub program Get Fact. Flowchart ini menggambarkan alur kerja dari sub program Get Fact yang berfungsi untuk mengidentifikasi link yang telah disimpan sebelumnya pada database. Link tersebut selanjutnya diproses satu per satu dan diidentifikasi setiap halamannya, untuk mendapatkan data berupa data animalia yang ada pada halaman web tersebut. Data yang berhasil didapatkan selanjutnya disimpan dalam database.

\section{c. Filter}

Filter merupakan sub proses yang berfungsi untuk melakukan mapping terhadap data yang berhasil diambil dari proses Get Fact sebelumnya. Data yang tersimpan pada proses Get Fact diperiksa satu per satu dalam proses filter. Data yang memenuhi syarat yang telah ditentukan dalam proses filter dimasukkan ke dalam database, sedangkan yang tidak memenuhi syarat maka dilewati. Alur kerja dari sub proses filter dapat dilihat pada Gambar 5. 


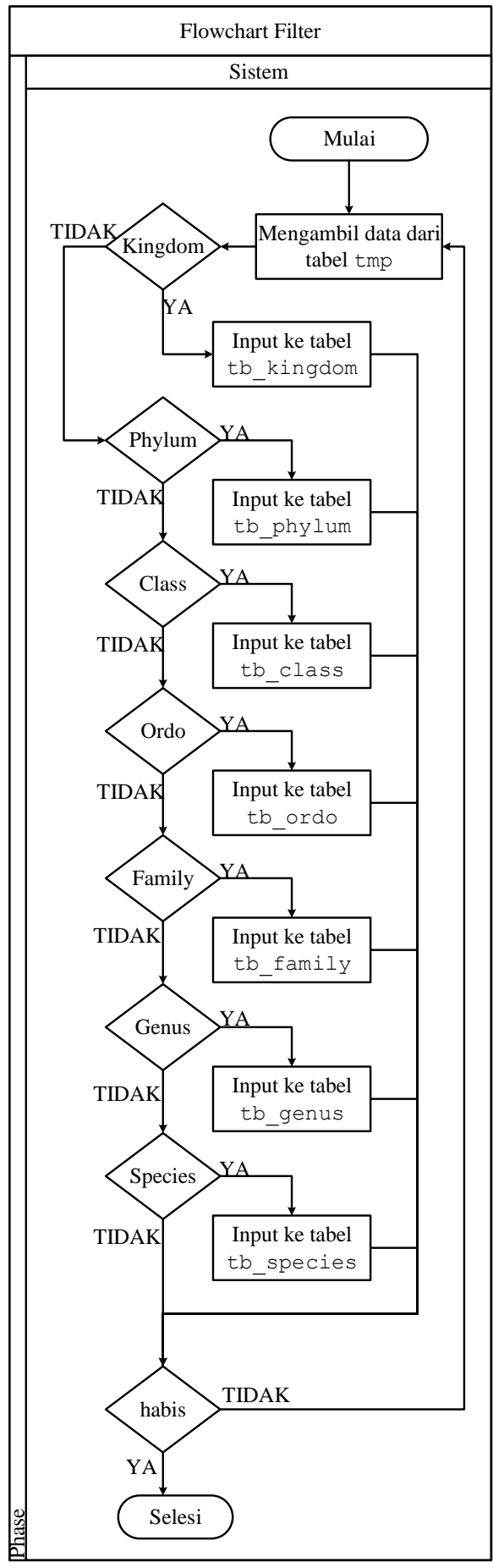

Gambar 5. Flowchart Filter

\subsection{Relationship tabel}

Relationship tabel merupakan gambaran yang menunjukkan hubungan antara tabel-tabel yang telah dirancang sebelumnya. Relationship tabel dapat dilihat pada Gambar 6. 


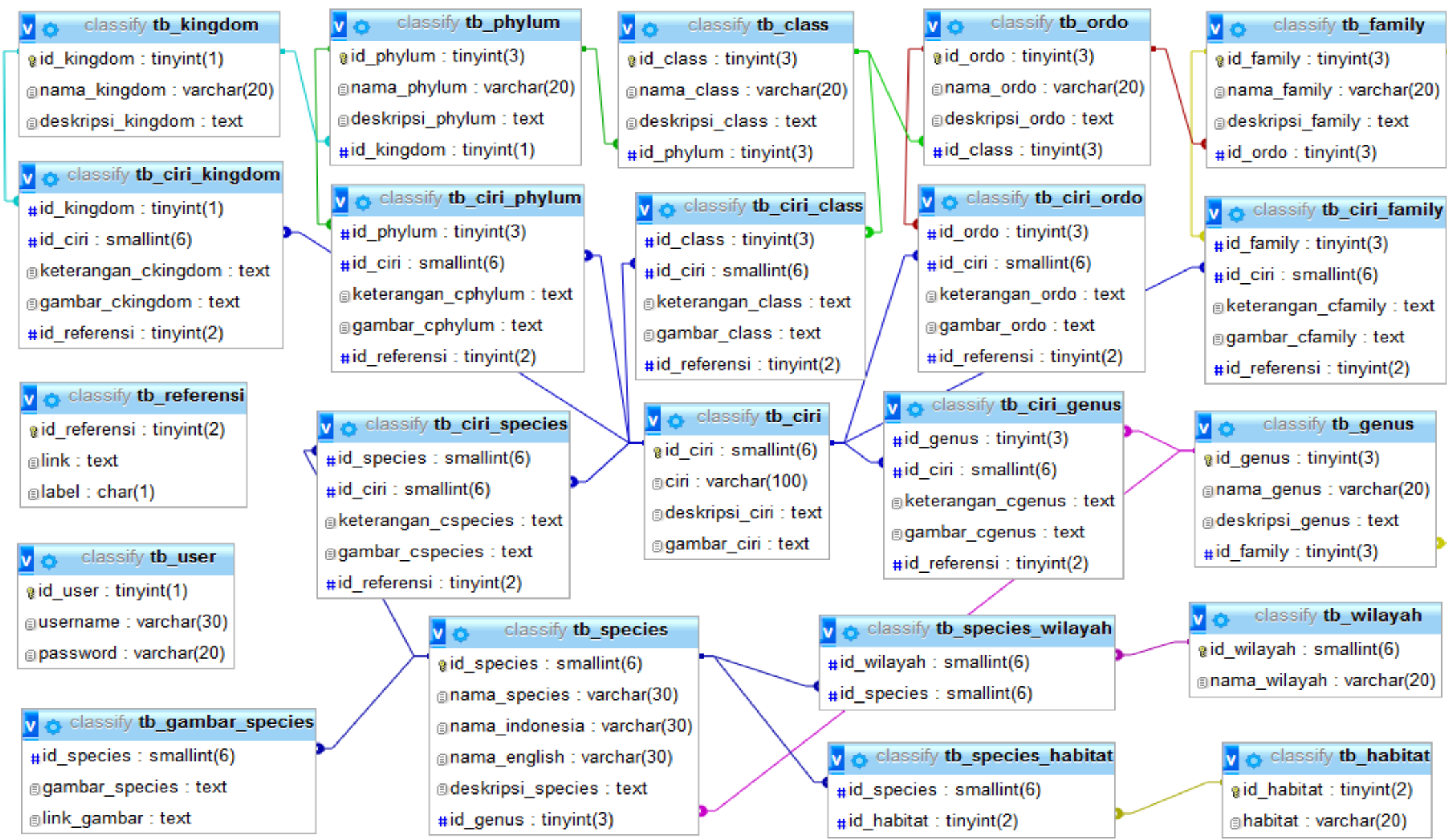

Gambar 6. Relationship tabel 


\section{Kajian Pustaka}

\subsection{Klasifikasi}

Sistem klasifikasi makhluk hidup terus berkembang hingga saat ini, karena adanya penemuanpenemuan baru yang dikembangkan oleh manusia. Sistem klasifikasi makhluk hidup bermula pada abad ke-19 sampai 20 masih menggunakan sistem dua kingdom, yaitu dunia tumbuhan (Plantarum) dan dunia hewan (Animalia). Penelitian yang dilakukan oleh Michael A. Ruggiero dan timnya memecah kingdom menjadi 7 bagian yang sebelumnya archae dan bacteria menjadi satu kini dipisah menjadi kingdom yang berbeda. Sistem klasifikasi 7 kingdom terdiri atas Kingdom Bacteria, Kingdom Archaea, Kingdom Protozoa, Kingdom Chromista, Kingdom Fungi, Kingdom Plantae dan Kingdom Animalia yang [8]. Klasifikasi adalah cara untuk melakukan pengelompokan terhadap makhluk hidup berdasarkan ciri-ciri tertentu. Tujuan dari klasifikasi adalah:

1. Melakukan pengelompokan pada makhluk hidup berdasarkan ciri-ciri yang dimiliki;

2. Menjelaskan mengenai ciri-ciri dari suatu jenis makhluk hidup agar dapat membedakan dengan jenis yang lainnya;

3. Mencari hubungan kekerabatan dari makhluk hidup yang ada;

4. Memberi nama kepada makhluk hidup yang tidak memiliki nama sebelumnya.

\subsection{Tingkat Takson}

Klasifikasi terdiri atas beberapa tingkatan, mulai dari kelompok besar, kemudian dibagi menjadi beberapa kelompok kecil, selanjutnya kelompok kecil dibagi menjadi beberapa kelompok kecil lagi sehingga terbentuk kelompok-kelompok yang lebih kecil yang hanya mempunyai anggota satu jenis makhluk hidup.

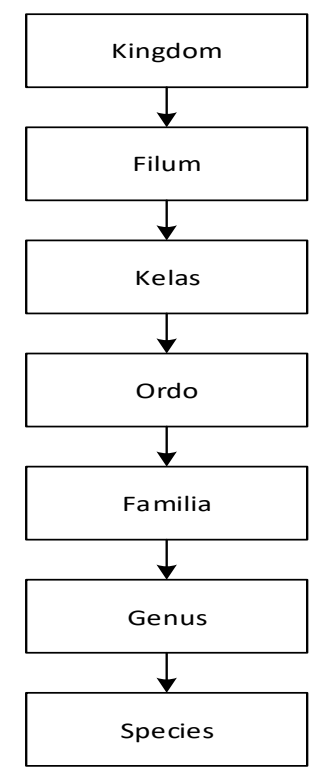

Gambar 7. Tingkatan Takson pada Kingdom Animalia

Gambar 7 merupakan tingkatan takson dari Kingdom Animalia. Takson tersebut tersusun dari tingkat tertingginya yaitu kingdom hingga yang terendah spesies, semakin tinggi tingkatan dari takson, maka persamaan ciri yang dimiliki akan semakin umum. Tingkatan takson yang semakin rendah, maka kesamaan ciri yang dimiliki makhluk hidup semakin khusus.

\subsection{Struktur Data Tree}

Metode tree atau pohon adalah sejumlah node yang berhubungan secara hirarkis dimana suatu node pada suatu hirarki merupakan cabang dari node dengan hirarki yang lebih tinggi dan juga memiliki cabang ke beberapa node lainnya dengan hirarki yang lebih rendah [9]. Metode tree dalam ilmu komputer adalah suatu struktur data yang digunakan secara luas yang menyerupai 
struktur pohon dengan sejumlah simpul yang terhubung [10]. Contoh apllikasi yang menggunakan metode tree adalah Sistem Informasi Upacara yadnya Berbasis Android [11].

\subsection{Web Scraping}

Web Scraping merupakan metode untuk mengambil dokumen sebuah website dari internet, yang berupa HTML maupun XHTML dan selanjutnya dilakukan analisis untuk diambil data tertentu dari dokumen tersebut. Data yang diambil dengan web scraping seperti link, gambar, maupun berita yang terdapat dalam sebuah website [2].

\section{Hasil dan Pembahasan}

Hasil dan pembahasan memaparkan mengenai hasil analisa dan pengujian pada aplikasi yang telah dikembangkan.

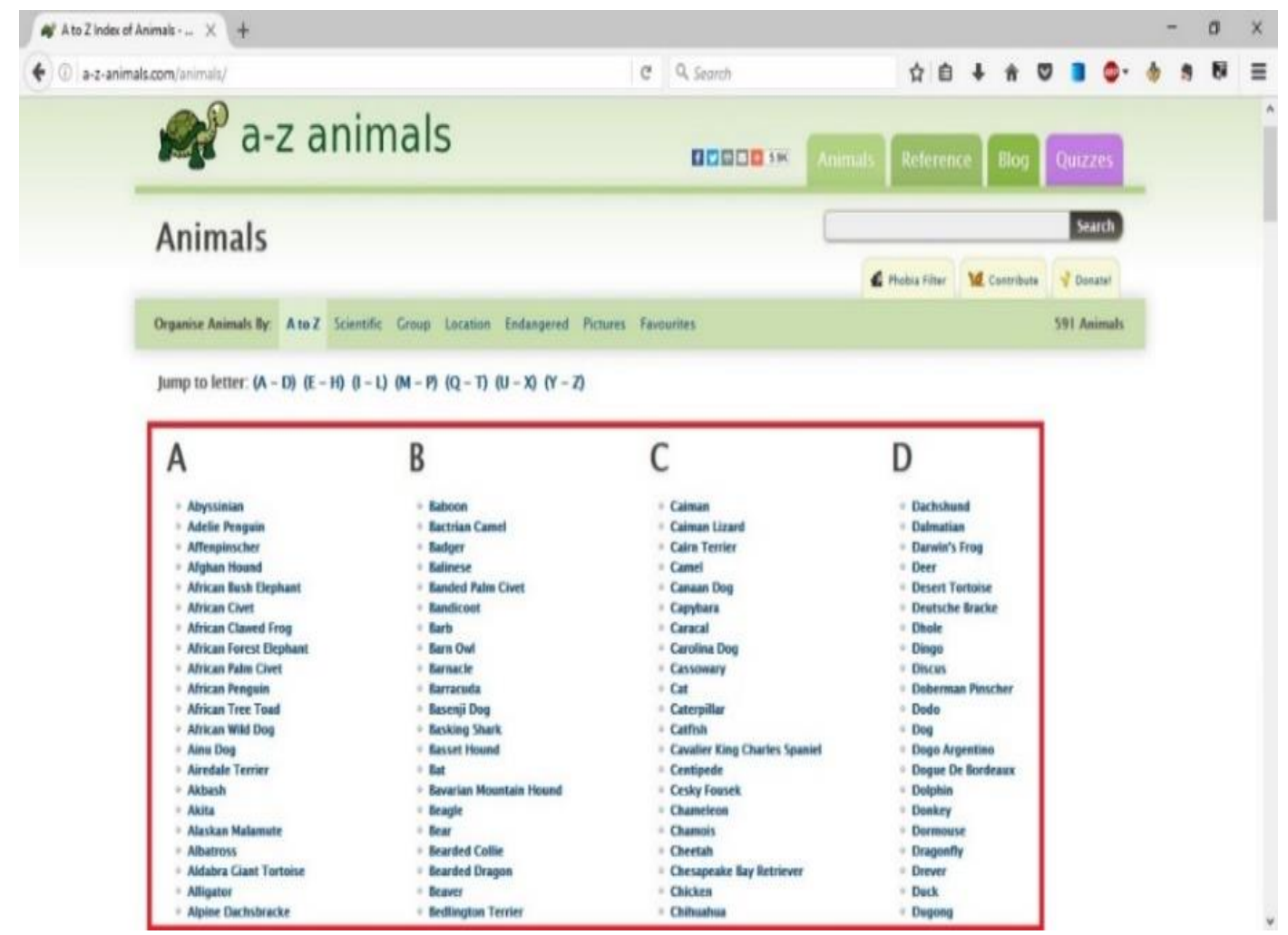

Gambar 8. Halaman a-z animals

Gambar 8 merupakan tampilan dari halaman animals dari website a-z-animals. Bagian yang diberi kotak merah adalah bagian yang dilakukan proses pengambilan data. Seluruh link pada bagian yang diberi kotak merah itu diambil dan disimpan ke dalam database oleh program. 


\begin{tabular}{|c|c|c|c|c|c|c|c|}
\hline Show 10 & $\checkmark$ entries & \multicolumn{4}{|c|}{ Search: } & & \\
\hline NO- & LINK & $\rightarrow$ & \multicolumn{3}{|c|}{ STATUS $\Rightarrow$} & \multicolumn{2}{|c|}{ ACTION $\rightarrow$} \\
\hline 1 & \multicolumn{2}{|l|}{ http://www.catalogueoflife.org/col/details/species/id/b481959b65f831cf3fe888a052c74ad7/source/tree } & \multicolumn{2}{|c|}{ Checked } & \multicolumn{3}{|c|}{ CEdit| XDelete } \\
\hline 2 & \multicolumn{2}{|l|}{ http://www.catalogueoflife.org/col/details/species/id/e5850208ceff1e76bb48ee50ab2394d5/source/tree } & \multicolumn{2}{|c|}{ Checked } & \multicolumn{3}{|c|}{ CEdit $\mid \mathbf{x D e l e t e}$} \\
\hline 3 & \multicolumn{2}{|l|}{ http://www.catalogueoflife.org/col/details/species/id/9b5442332562286347009e34977a39bf/source/tree } & \multicolumn{2}{|c|}{ Checked } & \multicolumn{3}{|c|}{ CEdit $\mid \mathbf{x D e l e t e}$} \\
\hline 4 & \multicolumn{2}{|l|}{ http://www.catalogueoflife.org/col/details/species/id/93a09f310f8273c81a556f4778af896f/source/tree } & \multicolumn{2}{|c|}{ Uncheked } & \multicolumn{3}{|c|}{ CEdit $\mid \times$ Delete } \\
\hline 5 & \multicolumn{2}{|l|}{ http://www.catalogueoflife.org/col/details/species/id/222a428261b75966c0d5de31d95f5419/source/tree } & \multicolumn{2}{|c|}{ Uncheked } & \multicolumn{3}{|c|}{ CEdit $\mid \mathbf{x D e l e t e}$} \\
\hline 6 & \multicolumn{2}{|l|}{ http.//www.catalogueoflife.org/col/details/species/id/1aa52e26fce7357b48d6d8a0b03c9ba1/source/tree } & \multicolumn{2}{|c|}{ Uncheked } & \multicolumn{3}{|c|}{ CEdit| $\mathbf{x}$ Delete } \\
\hline 7 & \multicolumn{2}{|l|}{ http://www.catalogueoflife.org/col/details/species/id/1c62a268fe49080730d30c447de258fd/source/tree } & \multicolumn{3}{|c|}{ Uncheked } & \multicolumn{2}{|c|}{ CEdit $\mid \times$ Delete } \\
\hline 8 & \multicolumn{2}{|l|}{ http://www.catalogueoflife.org/col/details/species/id/0fbaebc98ce5b28118ee36bd26096ced/source/tree } & \multicolumn{2}{|c|}{ Uncheked } & \multicolumn{3}{|c|}{ CEEdit | XDelete } \\
\hline 9 & \multicolumn{2}{|l|}{ http://www.catalogueoflife.org/col/details/species/id/ca52f0aa78abb2a453590c004574a908/source/tree } & \multicolumn{3}{|c|}{ Uncheked } & \multicolumn{2}{|c|}{ ¿Edit| $\mathbf{x}$ Delete } \\
\hline 10 & \multicolumn{2}{|l|}{ http://www.catalogueoflife.org/col/details/species/id/ece7cacc050c03039727dcaf5f72b24b/source/tree } & \multicolumn{3}{|c|}{ Uncheked } & \multicolumn{2}{|c|}{ CEdit | XDelete } \\
\hline Showing 1 & to 10 of 201 entries & 12 & 3 & 4 & & 21 & Next \\
\hline
\end{tabular}

Gambar 9. Hasil Pengambilan Link

Gambar 9 menampilkan hasil dari link yang telah disimpan setelah proses pengambilan link selesai. Proses selanjutnya melakukan pengecekan terhadap link yang telah tersimpan di dalam database.

\section{African Bush Elephant}

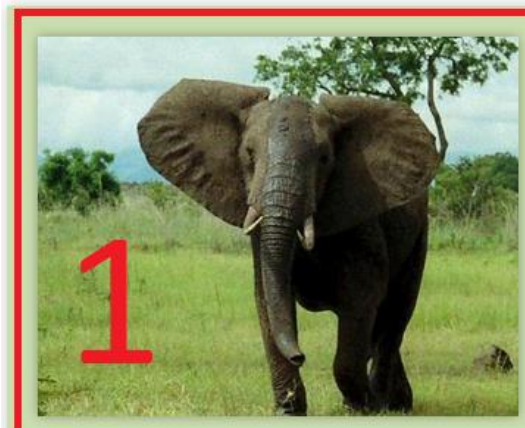

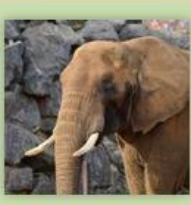
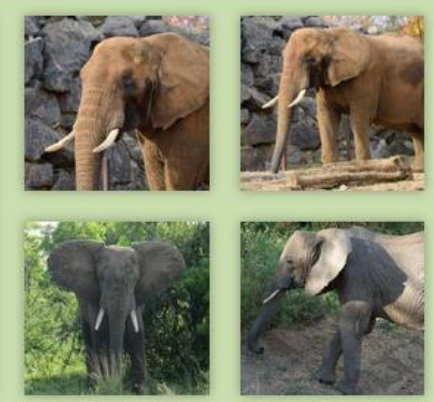
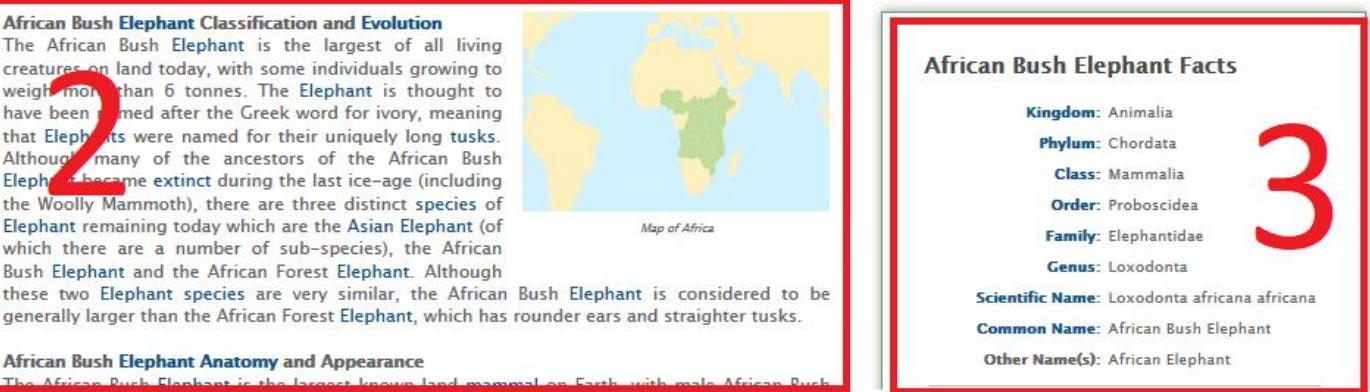

Gambar 10. Tabel Facts a-z animals

Gambar 10 merupakan tampilan dari halaman yang dilakukan proses scraping. Halaman ini diambil dari link yang tersimpan dalam database dari proses sebelumnya. Program membaca link tersebut satu per satu dan menampilkan halaman seperti Gambar 10. Terdapat tiga buah kotak merah pada halaman tersebut, kotak merah tersebut menunjukkan bagian yang diambil datanya. 
Kotak nomor satu mengambil data berupa link dari gambar yang di tampilkan, kotak nomor dua mengambil deskripsi dari spesies tersebut dan kotak nomor tiga mengambil data berupa fakta dari spesies tersebut. Bagian tersebut yang diproses dan data yang berhasil diambil dimasukkan ke dalam database.

\begin{tabular}{|c|c|c|c|c|}
\hline id & th & & td & \\
\hline 1 & Kingdom & $7 \mathrm{~B}$ & Animalia & $8 B$ \\
\hline 2 & Phylum & $6 \mathrm{~B}$ & Chordata & $8 \mathrm{~B}$ \\
\hline 3 & Class & $5 B$ & Mammalia & $8 \mathrm{~B}$ \\
\hline 4 & Order & $5 B$ & Tubulidentata & $13 \mathrm{~B}$ \\
\hline 5 & Family & $6 \mathrm{~B}$ & Orycteropodidae & $15 B$ \\
\hline 6 & Genus & $5 B$ & Orycteropus & $11 \mathrm{~B}$ \\
\hline 7 & Scientific Name & $15 B$ & Orycteropus ... & $16 \mathrm{~B}$ \\
\hline 8 & Common Name & $11 \mathrm{~B}$ & Aardvark & $8 \mathrm{~B}$ \\
\hline 9 & Group & $5 B$ & Mamma 1 & $6 \mathrm{~B}$ \\
\hline 10 & Habitat & $7 \mathrm{~B}$ & Sandy and $\mathrm{cl} .$. & $19 B$ \\
\hline
\end{tabular}

Gambar 11. Hasil Scraping

Gambar 11 merupakan hasil dari proses scraping yang telah dilakukan, dari Gambar 11 menampilkan data yang berasal dari halaman web seperti yang ditampilkan pada Gambar 10 pada kotak berwarna merah.
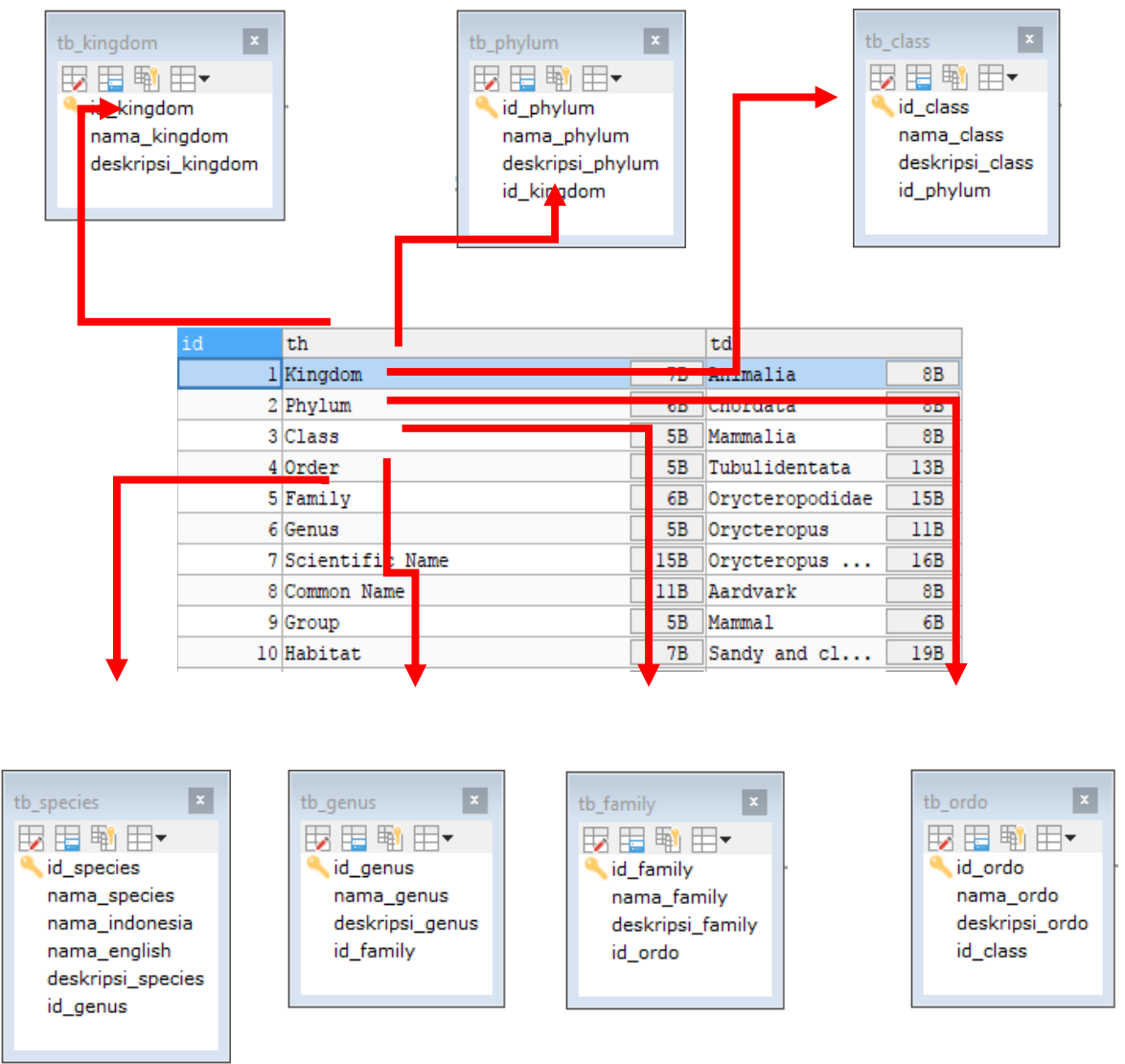

Gambar 12. Hasil Scraping

Gambar 12 menjelaskan mengenai mapping terhadap data yang telah berhasil disimpan ke dalam database. Mapping dilakukan jika proses pengambilan data sebelumnya sudah selesai. Data yang tersimpan dalam tabel tersebut dipindahkan ke masing-masing tabel seperti yang terlihat pada Gambar 12. Data Kingdom dimasukkan ke dalam tb_kingdom, data Phylum 
dimasukkan ke dalam tb_phylum, data Class dimasukkan ke dalam tb_class, data Order dimasukkan ke dalam tb_ordo, data Family dimasukkan ke dalam tb_family, data Genus dimasukkan ke dalam tb_genus dan data Scientific Name dimasukkan ke dalam tb_species.

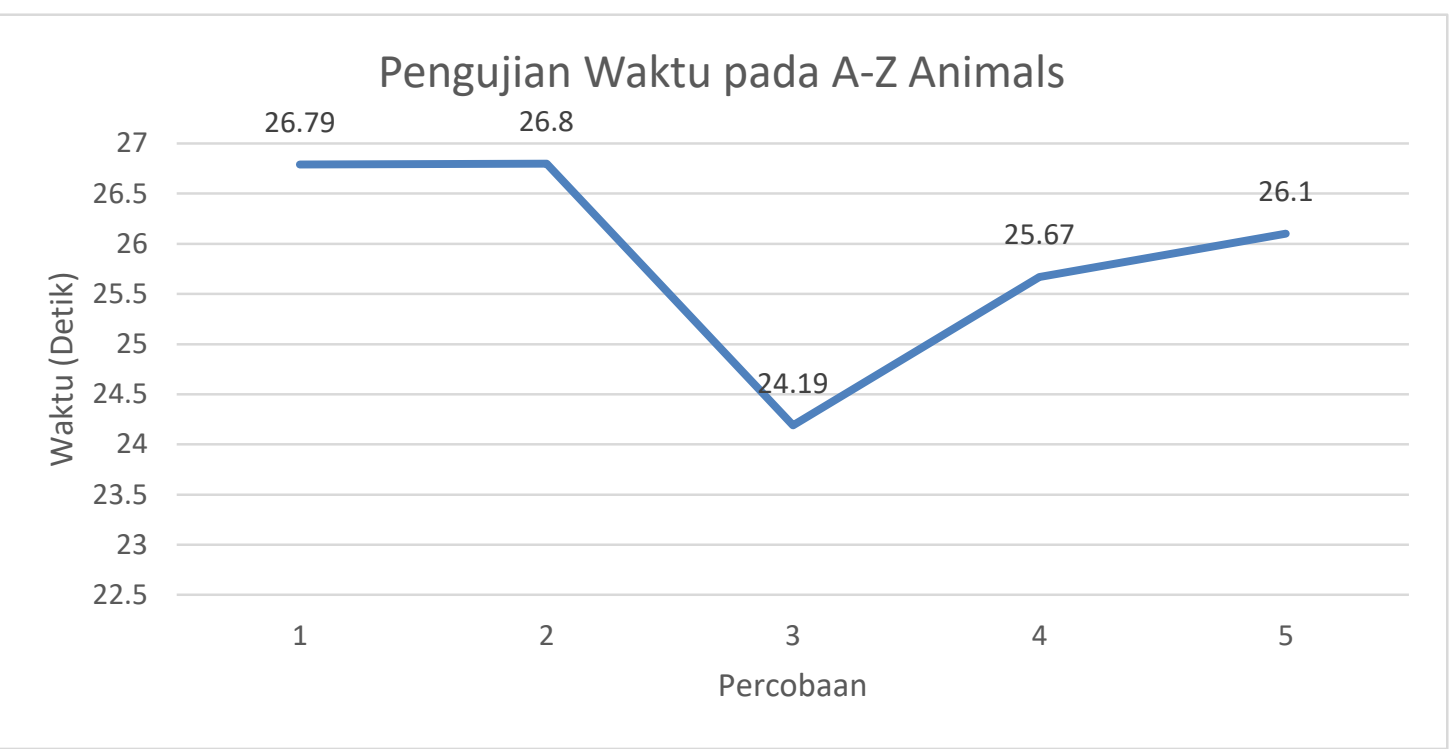

Gambar 13. Grafik Pengujian Waktu Pengambilan Link

Gambar 13 merupakan waktu rata-rata yang didapatkan dari pengujian sebanyak lima kali. a-zanimals.com membutuhkan waktu rata-rata 25.91 detik dan dapat mengambil data sebanyak 626 buah.

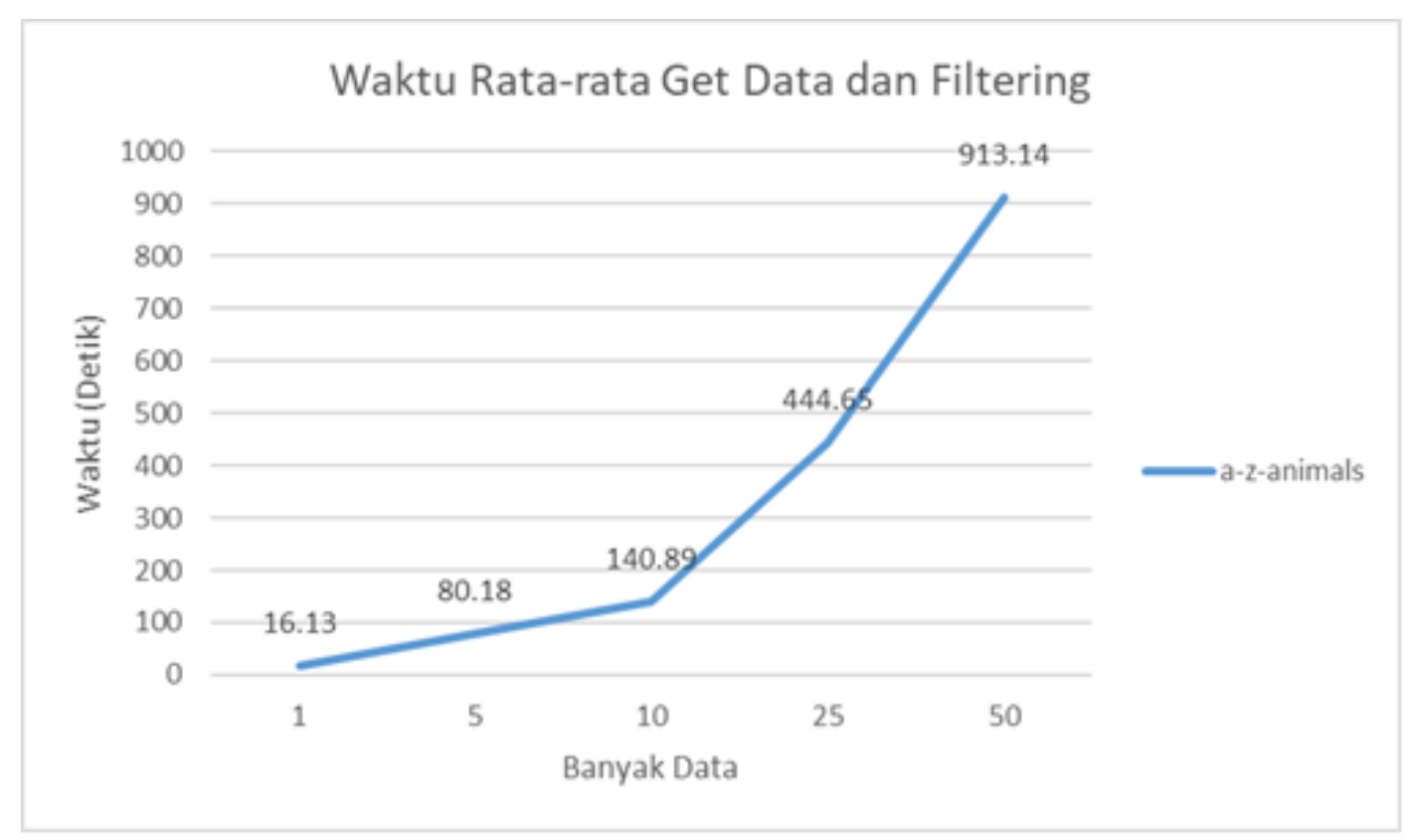

Gambar 14. Waktu Rata-rata Get Data dan Filtering a-z-animal

Pengambilan data dan filtering dari website a-z-animals.com setelah melakukan pengujian sebanyak tiga kali mendapatkan waktu rata-rata seperti yang terdapat pada Gambar 14.

\section{Kesimpulan}

Pengambilan konten atau data dari sebuah website melalui beberapa tahapan. Tahapan pertama adalah mempelajari struktur HTML dari website, yang bertujuan untuk menentukan bagian website yang ingin diambil datanya. Tahap kedua adalah memahami teknik navigasi pada 
website, untuk selanjutnya ditirukan pada aplikasi web scraper agar dapat melakukan pencarian terhadap data yang diinginkan. Tahap ketiga adalah membuat otomatisasi program berdasarkan informasi yang didapatkan dari tahap satu dan dua. Tahap keempat yaitu melakukan penyimpanan data yang berhasil didapatkan ke database. Data yang didapatkan dari website az-animal.com berupa data takson, deskripsi dari hewan dan gambar dari hewan tersebut. Aplikasi akan mencari data tersebut berdasarkan syarat yang telah ditentukan pada saat tahap mempelajari struktur HTML website. Pengujian yang telah dilakukan menunjukkan bahwa waktu yang diperlukan aplikasi dalam proses pengambilan data link a-z-animal.com adalah sekitar 25.91 detik dan data yang didapatkan sebanyak 626 buah. Aplikasi membutuhkan waktu ratarata memproses satu buah halaman a-z-animal.com adalah sekitar 16.13 detik.

\section{Daftar Pustaka}

[1] B. A. Nandari and Sukadi, "Pembuatan Website Portal Berita Desa Jetis Lor," IJNS, vol. 3, no. 3, pp. 43-47, 2014.

[2] A. Josi, L. A. Abdillah, and Suryayusra, "Penerapan Teknik Web Scrapping pada Mesin Pencari Artikel IImiah," Jurnal Sistem Informasi, vol. 5, no. 2, pp. 159-164, 2014.

[3] I. D. G. W. Dhiyatmika, I. K. D. Putra, and N. M. I. M. Mandenni, "Aplikasi Augmented Reality Magic Book Pengenalan Binatang untuk Siswa TK," Lontar Komputer : Jurnal Ilmiah Teknologi Informasi, vol. 6, no. 2, pp. 120-127, 2015.

[4] Wamiliana, D. Kurniasari, and J. S. Nugraha, "Pembuatan Media Pembelajaran Pengenalan Tata Surya dan Exoplanet Dengan Menggunakan Unity untuk Sekolah Menengah Pertama," Jurnal Komputasi, vol. 1, no. 1, pp. 47-57, 2013.

[5] F. Polidoro, R. Giannini, R. L. Conte, S. Mosca, and F. Rossetti, "Web scraping techniques to collect data on consumer electronics and airfares for Italian HICP compilation," Statistical Journal of the IAOS, pp. 165-176, 2015.

[6] M. A. Pise and P. J. Adhikari, "A Review: Data Extraction from multiple web databases," IJRITCC, vol. 3, no. 10, pp. 5930-5932, 2015.

[7] M. S. Utomo, "Web Scraping pada Situs Wikipedia menggunakan Metode Ekspresi Regular," Jurnal Teknologi Informasi DINAMIK vol. 18, no. 2, pp. 153-160, 2013.

[8] M. A. Ruggiero, D. P. Gordon, T. M. Orrell, N. Bailly, T. Bourgoin, R. C. Brusca, et al., "A Higher Level Classification of All Living Organisms," PLOS ONE, pp. 1-54, 2015.

[9] I. G. B. A. Pinatih, A. A. K. Oka Sudana, and I. K. Adi Purnawan, "E-Banjar Bali, Population Census Management Information System of Banjar in Bali by Using Family Tree Method and Balinese Culture Law," Journal of Theoretical and Applied Information Technology, vol. 59, no. 2, pp. 411-420, 2014.

[10] A. A. K. Oka Sudana, I. W. G. M. Kepakisan, and N. K. D. Rusjayanthi, "Implementation of Tree Structure and Recursive Algorithm for Balinese Traditional Snack Recipe on Android Based Application " International Journal of Interactive Mobile Technologies, vol. 10, no. 4, pp. 43-47, 2016.

[11] I. M. W. Saputra, A. A. K. Oka Sudana, and I. M. Sukarsa, "Implementasi Struktur Data tree pada Sistem Informasi Upacara yadnya Berbasis Android," Lontar Komputer : Jurnal IImiah Teknologi Informasi, vol. 2, no. 1, pp. 326-334, 2014. 